\title{
Planctomycetes and macroalgae, a striking association
}

\author{
Olga M. Lage ${ }^{1,2 *}$ and Joana Bondoso ${ }^{1,2}$ \\ ${ }^{1}$ Department of Biology, Faculty of Sciences, University of Porto, Porto, Portugal \\ ${ }^{2}$ CIMAR/CIIMAR - Interdisciplinary Centre for Marine and Environmental Research, University of Porto, Porto, Portugal
}

\section{Edited by:}

Luis Raul Comolli, Lawrence

Berkeley National Laboratory, USA

Reviewed by:

Mia Bengtsson, University of

Vienna, Austria

Onur Erbilgin, University of

California, Berkeley, USA

\section{${ }^{*}$ Correspondence:}

Olga M. Lage, Department of

Biology, Faculty of Sciences,

University of Porto, Rua do Campo

Alegre, s/n, 4169-007 Porto, Portugal

e-mail: olga.lage@fc.up.pt
Planctomycetes are part of the complex microbial biofilm community of a wide range of macroalgae. Recently, some studies began to unveil the great diversity of Planctomycetes present in this microenvironment and the interactions between the two organisms. Culture dependent and independent methods revealed the existence of a great number of species but, so far, only less than 10 species have been isolated. Planctomycetes comprise the genera Rhodopirellula, Blastopirellula, and Planctomyces, Phycisphaera and the uncultured class OM190 and some other taxa have only been found in this association. Several factors favor the colonization of macroalgal surfaces by planctomycetes. Many species possess holdfasts for attachment. The macroalgae secrete various sulfated polysaccharides that are the substrate for the abundant sulfatases produced by planctomycetes. Specificity between planctomycetes and macroalgae seem to exist which may be related to the chemical nature of the polysaccharides produced by each macroalga. Furthermore, the peptidoglycan-free cell wall of planctomycetes allows them to resist the action of several antimicrobial compounds produced by the macroalgae or other bacteria in the biofilm community that are effective against biofouling by other microorganisms. Despite the increase in our knowledge on the successful planctomycetes-macroalgae association, a great effort to fully understand this interaction is needed.

Keywords: planctomycetes, macroalgae, biofilm, association, macroalgae exudates

\section{INTRODUCTION}

Planctomycetes are a peculiar group of bacteria within the Planctomycetes, Verrucomicrobia, Chlamydiae (PVC) superphylum. They share with archaea or eukaryotes some distinctive characteristics such as peptidoglycan-less cell walls of proteic nature (Lage, 2013), a complex system of endomembranes forming a unique cell plan (Lage et al., 2013; Santarella-Mellwig et al., 2013), the presence of compartments like the anammoxosome (Van Teeseling et al., 2013), budding reproduction in many of their members (Ward et al., 2006) and the lack of the division protein FtsZ (Pilhofer et al., 2008), endocytosis (Lonhienne et al., 2010) and the presence of membrane coat (MC) - like proteins (Santarella-Mellwig et al., 2010). Some of these features place planctomycetes in the center of the discussion of the eukaryotic cell origin (Devos and Reynaud, 2010; Reynaud and Devos, 2011; Fuerst and Sagulenko, 2013).

Metabolically, planctomycetes are mainly aerobic, mesophilic, and neutrophilic organisms. A particular group of planctomycetes, the anaerobic ammonium oxidation (anammox) species, are strict anaerobes. Their diversified metabolism allows them to colonize a wide variety of ecosystems ranging from aquatic (marine, brackish, freshwater, sediments, and marine snow) to terrestrial habitats as well as several extreme environments such as desert soils (Abed et al., 2010; Andrew et al., 2012), hypersaline environments (Baumgartner et al., 2009; Schneider et al., 2013), hot springs (Tekere et al., 2011; Bohorquez et al., 2012), acidophilic habitats (Ivanova and Dedysh, 2012; Lucheta et al., 2013), glacial waters (Liu et al., 2006; Zeng et al., 2013) and
Antarctic soils and waters (Newsham et al., 2010; Piquet et al., 2010), hydrocarbon polluted environments (Abed et al., 2011)and other polluted habitats (Reed et al., 2002; Chouari et al., 2003; Caracciolo et al., 2005; Akob et al., 2007; Halter et al., 2011). Furthermore, their association with a great number of diverse eukaryotic organisms has been reported. These include sponges (Webster et al., 2001; Pimentel-Elardo et al., 2003; Zhu et al., 2008; Costa et al., 2013), ascidians (Oliveira et al., 2013), corals (Yakimov et al., 2006; Webster and Bourne, 2007; Duque-Alarcón et al., 2012), prawns (Fuerst et al., 1997), macrophytes (Hempel et al., 2008) and lichens (Grube et al., 2012). They were also found in sphagnum peat bogs (Kulichevskaia et al., 2006), the rock below the lichens (Bjelland et al., 2011) and in the rizosphere of several plants (Jensen et al., 2007; Zhao et al., 2010; Zhang et al., 2013).

Recently, various studies showed that planctomycetes are widespread in the biofilm community of several species of macroalgae and present a high diversity (Bengtsson and Ovreas, 2010; Lachnit et al., 2011; Lage and Bondoso, 2011). Besides a fundamental role in the primary production, beds of macroalgae along ocean coastlines provide the needed structure complexity, habitat and food for a huge and variable community of organisms which range from microscopic forms to larger organisms like fishes. Macroalgae are the dominant habitatforming organisms on temperate coastlines (Campbell et al., 2014) and offer shelter for many forms of life that can thus avoid predation by higher forms in the food chain. This is particularly evident in the large brown algal kelp forests. At a 
microscopic scale, macroalgal surfaces harbor a rich community composed by bacteria, fungi, diatoms, protozoa, spores and larvae of marine invertebrates (Lachnit et al., 2011) that can benefit from the availability of a range of organic carbon sources produced by algae (Armstrong et al., 2001). Bacteria are dominant among primary colonizers (Lachnit et al., 2009). The two major groups are Bacteroidetes and Proteobacteria followed by Firmicutes, Actinobacteria, Verrucomicrobia, and Planctomycetes (Goecke et al., 2013). In this review, we explore several aspects of the interaction between planctomycetes and macroalgae, a topic that recently started to be unveiled.

\section{MACROALGAE THAT HARBOR PLANCTOMYCETES}

Planctomycetes are frequent colonizers of macroalgae from the three phyla, Chlorophyta (green algae), Rhodophyta (red algae) and Heterokontophyta (brown algae). Planctomycetes colonization was observed for ulvacean algae like Cladophora sp. (Yoon et al., 2014), Ulva compressa (Hengst et al., 2010), Ulva intestinalis (Hengst et al., 2010; Lachnit et al., 2011; Lage and Bondoso, 2011), Ulva australis (Longford et al., 2007; Burke et al., 2011), Ulva prolifera (Liu et al., 2010), and Ulva sp. (Lage and Bondoso, 2011; Bondoso et al., 2013). This group was also reported to be present in the green macroalgae Chara aspera (Hempel et al., 2008) and Caulerpa taxifolia (Meusnier et al., 2001). Epiphytic planctomycetes were also found in the red algae Porphyra umbilicalis (Miranda et al., 2013), Laurencia dendroidea (De Oliveira et al., 2012), Delisea pulchra (Longford et al., 2007), and Gracilaria vermiculophylla (Lachnit et al., 2011). Isolates were retrieved from Chondrus crispus, Mastocarpus stellatus, Gracilaria bursapastoris, Gelidium pulchellum, Grateloupia turuturu, and Porphyra dioica (Lage and Bondoso, 2011). The presence of planctomycetes on Chondrus crispus, Mastocarpus stellatus, and Porphyra dioica was detected by molecular methods (Bondoso et al., 2013). A novel order of planctomycetes containing one species isolated from Porphyra sp. was described (Fukunaga et al., 2009). $16 \mathrm{~S}$ rRNA clone libraries from the brown algae Fucus vesiculosus revealed a great diversity of planctomycetes (Lachnit et al., 2011). Planctomycetes were isolated from other brown algae like Fucus spiralis, Sargassum muticum, Laminaria sp. (Lage and Bondoso, 2011), and Laminaria hyperborea (Bengtsson and Ovreas, 2010). The presence of planctomycetes has also been confirmed in Fucus spiralis, Sargassum muticum by Bondoso et al. (2013) and in Saccharina latissima and L. digitata (Bengtsson, unpublished results). These data suggest that planctomycetes are widespread among macroalgae which can be used for the discovery of novel planctomycetes species.

\section{PLANCTOMYCETES ASSOCIATED WITH MACROALGAE}

Although the abundance of planctomycetes is usually observed to be low in marine environments (Rusch et al., 2007) and some macroalgae (Burke et al., 2011; Lachnit et al., 2011; Miranda et al., 2013), Bengtsson and Ovreas (2010) showed, by FISH, that planctomycetes are dominant on Laminaria hyperborean where they can account for up to $51-53 \%$ of the bacterial biofilm cells.

About $30 \%$ of all the studies on macroalgae bacterial communities report the presence of planctomycetes and almost $4 \%$ of sequences from these studies belong to the phylum Planctomycetes
(Hollants et al., 2013). Planctomycete communities on macroalgae can be highly diverse varying from only one to 24 OTUs at a $97 \%$ cut-off in the $16 \mathrm{~S}$ rRNA gene per macroalgae (Table 1). With the use of specific primers for planctomycetes, Bengtsson and Ovreas (2010) defined 16 OTUs associated with the kelp Laminaria hyperborea, each representing a different species and Bondoso et al. (2013), using PCR-DGGE, identified a total of 21 different OTUs associated with six macroalgae. In a pyrosequencing study, the red macroalga Porphyra umbilicalis was found to harbor 24 different OTUs belonging to planctomycetes (Miranda et al., 2013). In total, more than 60 potential different species of planctomycetes are associated with macroalgae and the majority were not isolated in pure culture (Figure 1). So far, only 10 species were isolated from macroalgae (Winkelmann and Harder, 2009; Bengtsson and Ovreas, 2010; Lage and Bondoso, 2011) on the basis of the $97 \%$ cut-off defined for species delineation (Stackebrandt, 2002) of which four were validly described (Fukunaga et al., 2009; Bondoso et al., 2014; Yoon et al., 2014). The communities of planctomycetes comprise mainly members related to the cultured genera Blastopirellula, Rhodopirellula, and Planctomyces (Figure 1) and to the class Phycisphaerae which contains the genera Phycisphaera and Algisphaera. The most abundant taxon reported in culture-independent studies is related to an isolate from Fucus spiralis, strain FC18 (Lage and Bondoso, 2011), and can be found in almost all the macroalgae studied but predominantly in the brown macroalgae Fucus sp. and Laminaria hyperborea. The uncultured class OM190 (SILVA taxonomy), a deeply branching group within the Planctomycetes, is also usually reported as being associated to macroalgae (Figure 1, Table 1).

The planctomycetes associated with red and brown macroalgae seem to have a higher diversity than the ones colonizing green algae (Figure 1 and Table 1). This finding was reported by Lachnit et al. (2011) where only one OTU was associated with Ulva intestinalis, but 7 and 6 OTUs were, respectively, associated with Delisea pulchra and Fucus vesiculosus.

The communities of planctomycetes comprise taxa that were never found before in other habitats, suggesting a specific association with the macroalgae. Thirty nine out of 116 total sequences present in databases were found to be limited to macroalgal surfaces. Moreover, the study performed by Bondoso et al. (2013) also suggested that this association is host-specific and does not change with the geographical location of the macroalgae.

\section{INTERACTIONS BETWEEN MACROALGAE AND PLANCTOMYCETES}

The dynamic marine environments where macroalgae live are affected by diverse biotic and abiotic factors which contribute to, and influence the microbial community of their biofilms. Fundamental for this biofilm formation is the complex chemistry of macroalgal surfaces composed of exudates of secondary metabolites and extracellular exopolymeric substances (EPS) (Goecke et al., 2013). The chemistry varies among macroalgal species making each species a unique microenvironment, which induces a unique microbial community. Planctomycetes should be able to adapt easily to these complex environments. They are highly responsive to changes in environmental conditions through complex adaptation machinery. This was observed in 


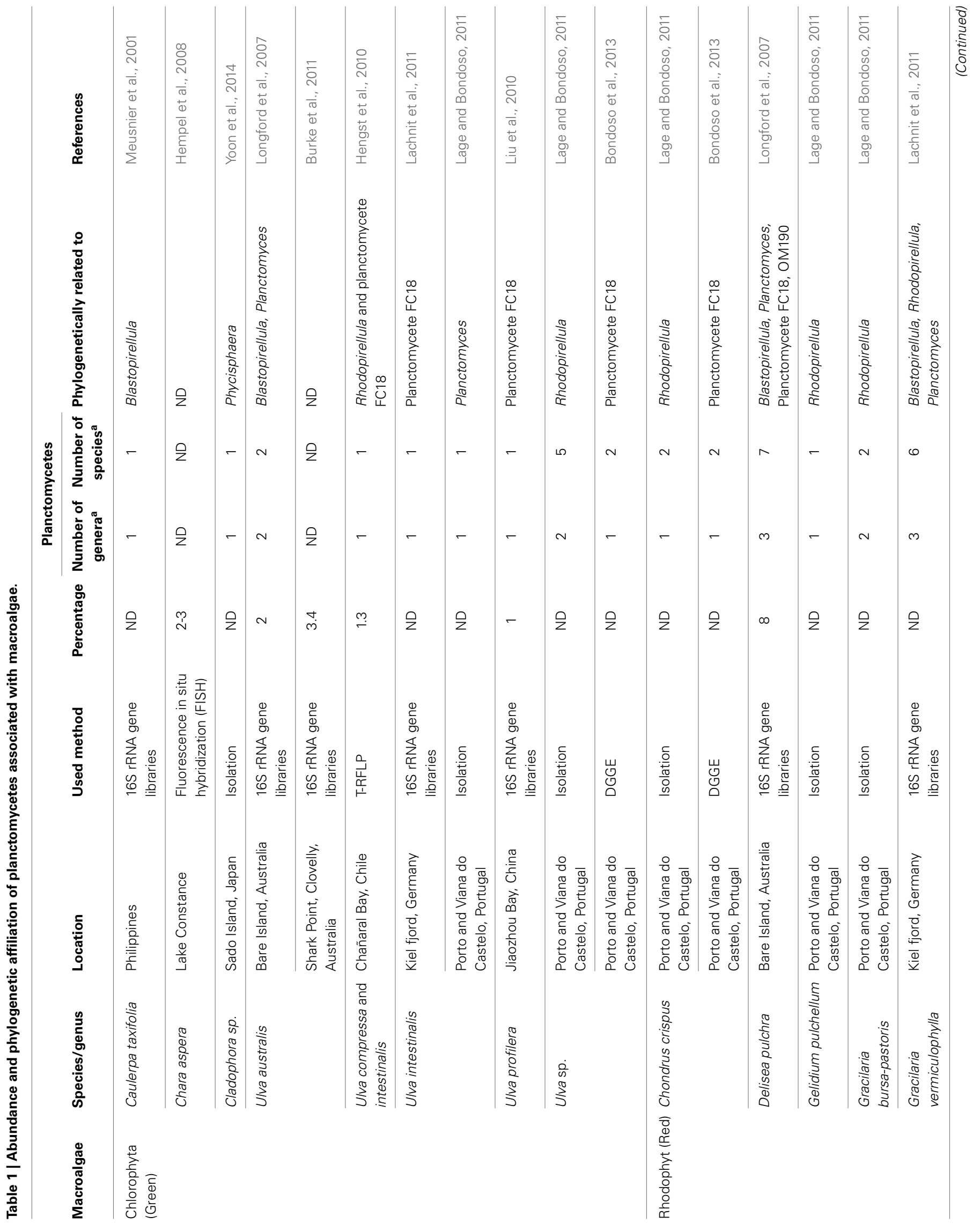




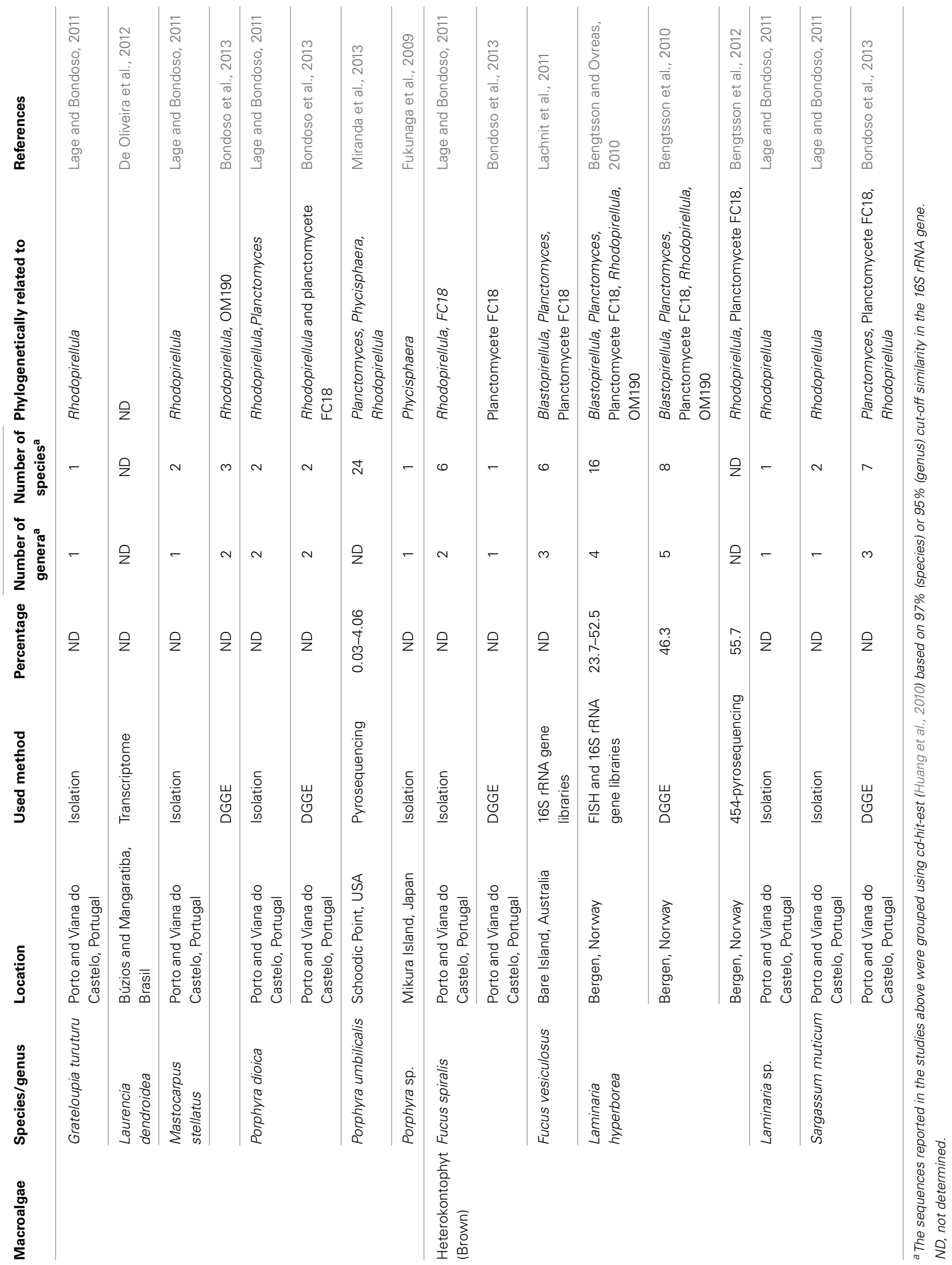




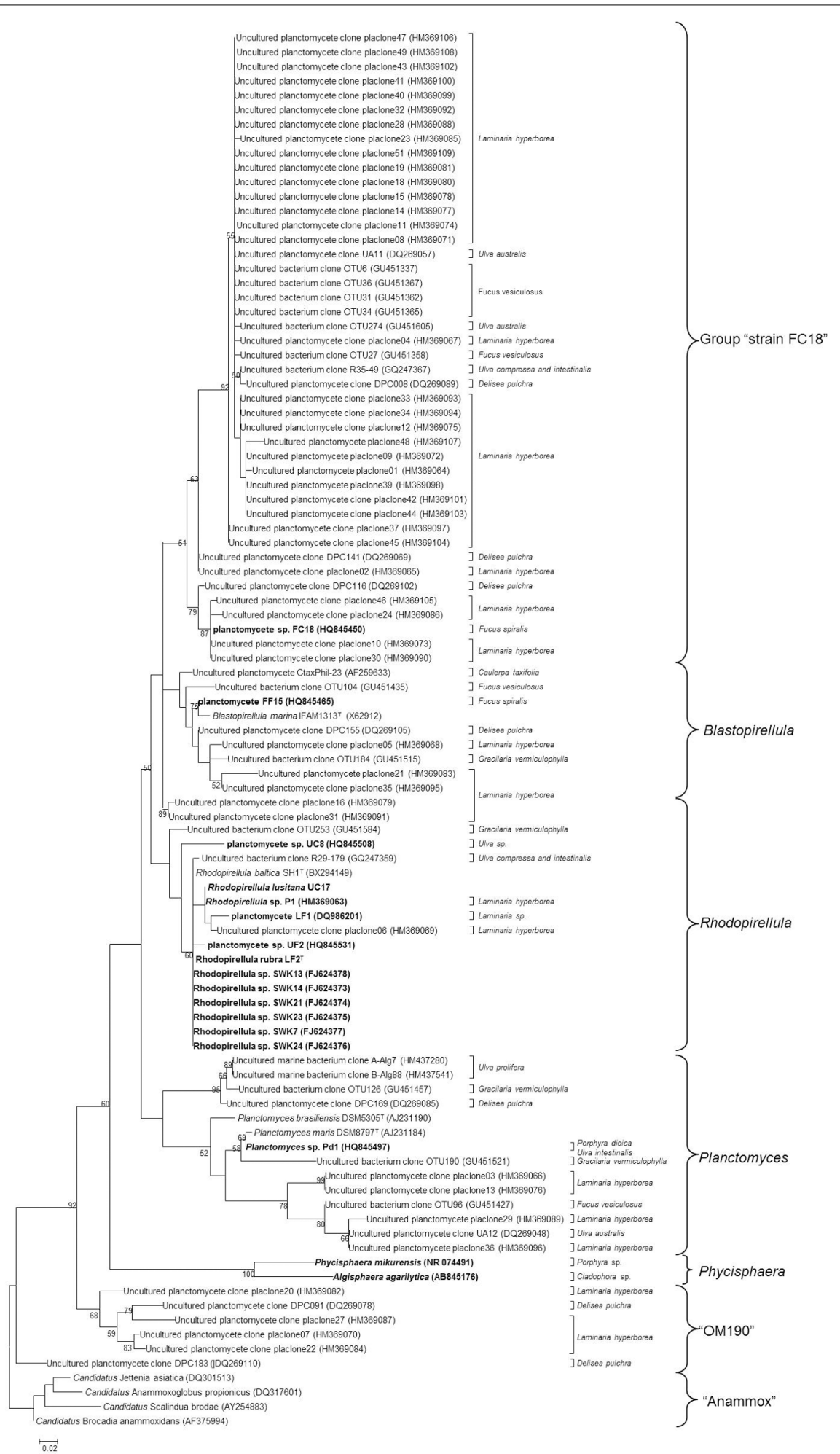

FIGURE 1 | Maximum-Likelihood tree of 16S rRNA gene sequences of planctomycetes associated with macroalgae downloaded from NCBI database. The final set consisted of 116 sequences above $500 \mathrm{bp}$. Strains in bold represent the isolates from macroalgae described to date. The numbers beside nodes are the percentages for bootstrap analyses; only values above $50 \%$ are shown. Scale bar $=0.02$ substitutions per 100 nucleotides. The different groups are presented on the right. Anammox 16S rRNA gene sequences were used as outgroup. 
Rhodopirellula baltica under stress response to temperature and salinity (Wecker et al., 2009).

Macroalgae produce or release many molecules that can be rich sources of substrates for planctomycetes nutrition. Algal macromolecules include sulfated polysaccharides like carrageenan and agar from red algae, alginate, fucan and laminarinan from brown algae and cellulose and ulvan from green algae. Planctomycetes are well tailored for the utilization of sulfated polysaccharides as revealed by the analysis of the marine R. baltica $\mathrm{SH}_{1}^{\mathrm{T}}$ genome where the presence of 110 sulphatases was detected (Glockner et al., 2003). Furthermore, Wegner et al. (2013) also found an exceptionally high number of sulphatase genes in the recently sequenced genomes of nine Rhodopirellula strains. These authors also verified in $R$. baltica $\mathrm{SH}^{\mathrm{T}}$ sulphatase expression profiles in cells grown on different sulfated polysaccharides. Polysaccharide utilization was also confirmed by the work of Jeske et al. (2013) where R. baltica was checked for potential utilization of several polymers. It was able to utilize laminarin, mannitol, pectin, chondroitin sulfate, N-acetylgalactosamine, and D-glucuronic acid. Cellobiose, a product of cellulose degradation, could also be used as carbon source. Weak or moderate degradation was obtained for mannan and its monomer $D$-mannose, the disaccharide sucrose and D-xylose. The novel species R. rubra and R. lusitana, both isolated from macroalgae, were shown to utilize the majority of the monomers that constitute the main polysaccharides secreted by macroalgae such as fucose, galactose, xylose, rhamnose, and manitol (Bondoso et al., 2014). Agarolytic activity was also described in a novel representative of the class Phycisphaera, Algisphaera agarilytica, isolated from the marine alga Cladophora sp. (Yoon et al., 2014). As frequent inhabitants of phytodetrial macroaggregates in marine environments, planctomycetes mineralize organic matter, intervening in important transformations in the global carbon cycle in the sea (DeLong et al., 1993). Very recently, Erbilgin et al. (2014) provided evidence by a metabolic activity screen that Bacterial Microcompartments (BMCs) present in planctomycetes are involved in the degradation of a number of plant and algal cell wall sugars, namely L-fucose and L-rhamnose. This work further supports the great relevance of algal exudates on planctomycetes physiology especially for those associated with macroalgae.

The different substrates produced by each macroalga may explain the specificity of planctomycetes to the algal host. It was found that the same algal species from two localities demonstrated high similarities in the composition of associated planctomycetes (Bondoso et al., 2013). A core of evidence seems to point to the algal host as the main factor controlling the composition and structure of epiphytic bacterial communities (Wahl, 2008; Lachnit et al., 2009, 2011; Hengst et al., 2010). Comparable results were reported for the epibiotic bacterial communities living on corals which seemed to be determined by the nature and composition of host exudates due to strong seasonal effects (Guppy and Bythell, 2006).

Planctomycetes colonize macroalgal surfaces; an attached life style has been well recognized for these bacteria and when in pelagic environments they are mainly associated with particles like marine snow (DeLong et al., 1993). The presence of a holdfast of glycoproteic nature (Lage, 2013; Lage et al., 2013) favors attachment and, thus, the colonization of surfaces (Gade et al., 2005; Lage, 2013; Lage et al., 2013).

Another factor that favors the colonization of macroalgal biofilms by planctomycetes is their ability to resist several antibiotics. These can be produced by the macroalgae or by other competing bacteria in the biofilm. One of the methods to achieve planctomycetes isolation in culture is precisely based on this resistance to antibiotics (Schlesner, 1994; Winkelmann and Harder, 2009; Lage and Bondoso, 2011). Resistance to $\beta$-lactam antibiotics that affect peptidoglycan biosynthesis is due to the absence of this molecule in their cell wall.

In a study of the behavior of planctomycetes toward antibiotics, Cayrou et al. (2010) showed that five reference strains of planctomycetes were resistant to $\beta$-lactams, to the quinolone nalidixic acid and to the glycopeptide vancomycin. The organisms were, however sensitive to tetracycline and doxycycline. Most were also resistant to chloramphenicol and the aminoglycoside gentamicin as well as rifampicin. A variable resistance to the association sulfomethoxazole/trimethoprim was obtained.

The potential benefits of the planctomycetes to the macroalgae can only be hypothesized. Being heterotrophs, planctomycetes can mineralize organic molecules producing inorganic compounds that meet the nutritional needs of macroalgae. These may also profit from the production of growth factors or antimicrobial molecules by the planctomycetes. It has been shown that morphogenetic factors like thallusin, isolated from an epiphytic marine bacterium, are indispensable to the foliaceous morphology of macroalgae (Matsuo et al., 2005). Unknown factors may be due to planctomycetes. The production of bioactive molecules by planctomycetes was initially searched by genome mining in $R$. baltica (Donadio et al., 2007) and subsequently in 13 genomes (Jeske et al., 2013). Two small nonribosomal peptide synthetases (NRPSs), two monomeric polyketide synthases (PKSs), and a bimodular hybrid NRPS-PKS were found in the genome of $R$. baltica which are probably involved in the synthesis of five different, unknown bioactive products (Donadio et al., 2007). In the 13 genomes analyzed, 102 genes or gene clusters putatively related with the production of secondary metabolites like bacteriocin encoding genes, putative lantibiotic-encoding gene, ectoine synthesis gene cluster, putative phenazine encoding gene cluster were found (Jeske et al., 2013). The potential production of these bioactive molecules may help the macroalgae to control their colonization by undesired bacteria or fungi. Furthermore, we can hypothesize that bioactive molecules should be important for planctomycetes in the process of macroalgal colonization and posterior defense against competitors.

Bacteria can also impact negatively on macroalgae. Members of Bacteroidetes and Gammaproteobacteria can induce several diseases like "shot hole disease" or "hole-rotten disease" (Goecke et al., 2013). Up to now, pathogenicity from planctomycetes on macroalgae was never reported.

\section{CONCLUSIONS}

As shown in this review, macroalgae are promising environments for in-depth study of planctomycetes. Macroalgae possess a relatively high number and a diverse community of planctomycetes in their biofilm. Thus, they represent great potential for 
the discovery of new taxa that can be isolated from these habitats and their characterization could provide new knowledge on the morphology, physiology and ecology of planctomycetes and on this interaction. New research on the structure, succession and dynamics of the community in this relationship, namely the relation with the macroalgal life cycle, the temporality of planctomycetes diversity and composition and their association with other macroalgae will give new highlights in the ecology of this interaction. Metabolomic approaches will allow obtaining insights into the mechanisms of the nutritional relationship and the role of planctomycetes in biofilm formation and maintenance. The increasing scientific interest in the biology of planctomycetes and biofilms will, most certainly, generate new exciting knowledge that will allow a better comprehension of this association.

\section{ACKNOWLEDGMENTS}

This research was supported by the European Regional Development Fund (ERDF) through the COMPETE Operational Competitiveness Programme and national funds through FCT - Foundation for Science and Technology, under the project PEst-C/MAR/LA0015/2013. The second author was financed by FCT (PhD grant SFRH/BD/35933/2007).

\section{REFERENCES}

Abed, R. M. M., Al Kharusi, S., Schramm, A., and Robinson, M. D. (2010). Bacterial diversity, pigments and nitrogen fixation of biological desert crusts from the Sultanate of Oman. FEMS Microbiol. Ecol. 72, 418-428. doi: 10.1111/j.15746941.2010.00854.x

Abed, R. M. M., Musat, N., Musat, F., and Mußmann, M. (2011). Structure of microbial communities and hydrocarbon-dependent sulfate reduction in the anoxic layer of a polluted microbial mat. Mar. Pollut. Bull. 62, 539-546. doi: 10.1016/j.marpolbul.2010.11.030

Akob, D. M., Mills, H. J., and Kostka, J. E. (2007). Metabolically active microbial communities in uranium-contaminated subsurface sediments. FEMS Microbiol. Ecol. 59, 95-107. doi: 10.1111/j.1574-6941.2006.00203.x

Andrew, D. R., Fitak, R. R., Munguia-Vega, A., Racolta, A., Martinson, V. G., and Dontsova, K. (2012). Abiotic factors shape microbial diversity in Sonoran desert soils. Appl. Environ. Microbiol. 78, 7527-7537. doi: 10.1128/AEM.01459-12

Armstrong, E., Yan, L., Boyd, K. G., Wright, P. C., and Burgess, J. G. (2001). The symbiotic role of marine microbes on living surfaces. Hydrobiologia 461, 37-40. doi: 10.1023/A:1012756913566

Baumgartner, L. K., Dupraz, C., Buckley, D. H., Spear, J. R., Pace, N. R., and Visscher, P. T. (2009). Microbial species richness and metabolic activities in hypersaline microbial mats: insight into biosignature formation through lithification. Astrobiology 9, 861-874. doi: 10.1089/ast.2008.0329

Bengtsson, M. M., and Ovreas, L. (2010). Planctomycetes dominate biofilms on surfaces of the kelp Laminaria hyperborea. BMC Microbiol. 10:261. doi: 10.1186/1471-2180-10-261

Bengtsson, M. M., Sjotun, K., Lanzen, A., and Ovreas, L. (2012). Bacterial diversity in relation to secondary production and succession on surfaces of the kelp Laminaria hyperborea. ISME J. 6, 2188-2198. doi: 10.1038/ismej.2012.67

Bengtsson, M. M., Sjotun, K., and Ovreås, L. (2010). Seasonal dynamics of bacterial biofilms on the kelp Laminaria hyperborea. Aquat. Microb. Ecol. 60, 71-83. doi: 10.3354/ame01409

Bjelland, T., Grube, M., Hoem, S., Jorgensen, S. L., Daae, F. L., Thorseth, I. H., et al. (2011). Microbial metacommunities in the lichen-rock habitat. Environ. Microbiol. Rep. 3, 434-442. doi: 10.1111/j.1758-2229.2010.00206.x

Bohorquez, L. C., Delgado-Serrano, L., Lopez, G., Osorio-Forero, C., KlepacCeraj, V., Kolter, R., et al. (2012). In-depth characterization via complementing culture-independent approaches of the microbial community in an acidic hot spring of the Colombian Andes. Microb. Ecol. 63, 103-115. doi: 10.1007/s00248011-9943-3

Bondoso, J., Albuquerque, L., Lobo-Da-Cunha, A., Da Costa, M. S., Harder, J., and Lage, O. M. (2014). Rhodopirellula lusitana sp. nov. and Rhodopirellula rubra sp. nov., isolated from the surface of macroalgae. Syst. Appl. Microbiol. doi: 10.1016/j.syapm.2013.11.004

Bondoso, J., Balagué, V., Gasol, J. M., and Lage, O. M. (2013). Community composition of the Planctomycetes associated with different macroalgae. FEMS Microbiol. Ecol. doi: 10.1111/1574-6941.12258

Burke, C., Thomas, T., Lewis, M., Steinberg, P., and Kjelleberg, S. (2011). Composition, uniqueness and variability of the epiphytic bacterial community of the green alga Ulva australis. ISME J. 5, 590-600. doi: 10.1038/ismej.2010.164

Campbell, A. H., Marzinelli, E. M., Vergés, A., Coleman, M. A., and Steinberg, P. D. (2014). Towards restoration of missing underwater forests. PLoS ONE 9:e84106. doi: 10.1371/journal.pone.0084106

Caracciolo, A. B., Grenni, P., Ciccoli, R., Di Landa, G., and Cremisini, C. (2005). Simazine biodegradation in soil: analysis of bacterial community structure by in situ hybridization. Pest Manag. Sci. 61, 863-869. doi: 10.1002/ ps.1096

Cayrou, C., Raoult, D., and Drancourt, M. (2010). Broad-spectrum antibiotic resistance of Planctomycetes organisms determined by Etest. J. Antimicrob. Chemother. 65, 2119-2122. doi: 10.1093/jac/dkq290

Chouari, R., Le Paslier, D., Daegelen, P., Ginestet, P., Weissenbach, J., and Sghir, A. (2003). Molecular evidence for novel planctomycete diversity in a municipal wastewater treatment plant. Appl. Environ. Microbiol. 69, 7354-7363. doi: 10.1128/AEM.69.12.7354-7363.2003

Costa, R., Keller-Costa, T., Gomes, N. C. M., Da Rocha, U. N., van Overbeek, L., and van Elsas, J. D. (2013). Evidence for selective bacterial community structuring in the freshwater sponge Ephydatia fluviatilis. Microb. Ecol. 65, 232-244. doi: 10.1007/s00248-012-0102-2

De Oliveira, L. S., Gregoracci, G. B., Silva, G. G., Salgado, L. T., Filho, G. A., AlvesFerreira, M., et al. (2012). Transcriptomic analysis of the red seaweed Laurencia dendroidea (Florideophyceae, Rhodophyta) and its microbiome. BMC Genomics 13:487. doi: 10.1186/1471-2164-13-487

DeLong, E. F., Franks, D. G., and Alldredge, L. (1993). Phylogenetic diversity of aggregate-attached vs. free-living marine bacterial assemblages. Limnol. Oceanogr. 38, 924-934. doi: 10.4319/lo.1993.38.5.0924

Devos, D. P., and Reynaud, E. G. (2010). Intermediate steps. Science 330, 1187-1188. doi: 10.1126/science. 1196720

Donadio, S., Monciardini, P., and Sosio, M. (2007). Polyketide synthases and nonribosomal peptide synthetases: the emerging view from bacterial genomics. Nat. Prod. Rep. 24, 1073-1109. doi: 10.1039/b514050c

Duque-Alarcón, A., Santiago-Vázquez, L. Z., and Kerr, R. G. (2012). A microbial community analysis of the octocoral Eunicea fusca. Electron. J. Biotechnol. 15, 1-9. doi: 10.2225/vol15-issue5-fulltext-11

Erbilgin, O., McDonald, K. L., and Kerfeld, C. A. (2014). Characterization of a planctomycetal organelle: a novel bacterial microcompartment for the aerobic degradation of plant saccharides. Appl. Environ. Microbiol. 80, 2193-2205. doi: 10.1128/AEM.03887-13

Fuerst, J. A., Gwilliam, H. G., Lindsay, M., Lichanska, A., Belcher, C., Vickers, J. E., et al. (1997). Isolation and molecular identification of planctomycete bacteria from postlarvae of the giant tiger prawn, Penaeus monodon. Appl. Environ. Microbiol. 63, 254-262.

Fuerst, J. A., and Sagulenko, E. (2013). Nested bacterial boxes: nuclear and other intracellular compartments in plactomycetes. J. Mol. Microbiol. Biotechnol. 23, 95-103. doi: 10.1159/000346544

Fukunaga, Y., Kurahashi, M., Sakiyama, Y., Ohuchi, M., Tokota, A., and Harayama, S. (2009). Phycisphaera mikurensis gen. nov., sp. nov., isolated from a marine alga, and proposal of phycisphaeraceae fam. nov., phycisphaerales ord. nov. and phycisphaerae classis nov. in the phylum planctomycetes. J. Gen. Appl. Microbiol. 55, 267-275. doi: 10.2323/jgam.55.267

Gade, D., Stuhrmann, T., Reinhardt, R., and Rabus, R. (2005). Growth phase dependent regulation of protein composition in Rhodopirellula baltica. Environ. Microbiol. 7, 1074-1084. doi: 10.1111/j.1462-2920.2005.00784.x

Glockner, F. O., Kube, M., Bauer, M., Teeling, H., Lombardot, T., Ludwig, W., et al. (2003). Complete genome sequence of the marine planctomycete Pirellula sp. strain 1. Proc. Natl. Acad. Sci. U. S. A. 100, 8298-8303. doi: 10.1073/pnas. 1431443100

Goecke, F., Thiel, V., Wiese, J., Labes, A., and Imhoff, J. F. (2013). Algae as an important environment for bacteria-phylogenetic relationships among new bacterial species isolated from algae. Phycologia 52, 14-24. doi: 10.2216/12-24.1

Grube, M., Köberl, M., Lackner, S., Berg, C., and Berg, G. (2012). Host-parasite interaction and microbiome response: effects of fungal infections on the 
bacterial community of the Alpine lichen Solorina crocea. FEMS Microbiol. Ecol. 82, 472-481. doi: 10.1111/j.1574-6941.2012.01425.x

Guppy, R., and Bythell, J. C. (2006). Environmental effects on bacterial diversity in the surface mucus layer of the reef coral Montastraea faveolata. Mar. Ecol. Prog. Ser. 328, 133-142. doi: 10.3354/meps328133

Halter, D., Cordi, A., Gribaldo, S., Gallien, S., Goulhen-Chollet, F., HeinrichSalmeron, A., et al. (2011). Taxonomic and functional prokaryote diversity in mildly arsenic-contaminated sediments. Res. Microbiol. 162, 878-887. doi: 10.1016/j.resmic.2011.06.001

Hempel, M., Blume, M., Blindow, I., and Gross, E. M. (2008). Epiphytic bacterial community composition on two common submerged macrophytes in brackish water and freshwater. BMC Microbiol. 8:58. doi: 10.1186/1471-2180-8-58

Hengst, M. B., Andrade, S., Gonzalez, B., and Correa, J. A. (2010). Changes in epiphytic bacterial communities of intertidal seaweeds modulated by host, temporality, and copper enrichment. Microb. Ecol. 60, 282-290. doi: 10.1007/s00248-010-9647-0

Hollants, J., Leliaert, F., De Clerck, O., and Willems, A. (2013). What we can learn from sushi: a review on seaweed-bacterial associations. FEMS Microbiol. Ecol. 83, 1-16. doi: 10.1111/j.1574-6941.2012.01446.x

Huang, Y., Niu, B., Gao, Y., Fu, L., and Li, W. (2010). CD-HIT Suite: a web server for clustering and comparing biological sequences. Bioinformatics 26, 680-682. doi: 10.1093/bioinformatics/btq003

Ivanova, A. O., and Dedysh, S. N. (2012). Abundance, diversity, and depth distribution of Planctomycetes in acidic northern wetlands. Front. Microbiol. 3:5. doi: 10.3389/fmicb.2012.00005

Jensen, S. I., Kühl, M., and Priemé, A. (2007). Different bacterial communities associated with the roots and bulk sediment of the seagrass Zostera marina. FEMS Microbiol. Ecol. 62, 108-117. doi: 10.1111/j.1574-6941.2007.00373.x

Jeske, O., Jogler, M., Petersen, J., Sikorski, J., and Jogler, C. (2013). From genome mining to phenotypic microarrays: Planctomycetes as source for novel bioactive molecules. Antonie Van Leeuwenhoek 104, 551-567. doi: 10.1007/s10482-0130007-1

Kulichevskaia, I. S., Pankratov, T. A., and Dedysh, S. N. (2006). Detection of representatives of the Planctomycetes in Sphagnum peat bogs by molecular and cultivation methods. Mikrobiologiia. 75, 389-396.

Lachnit, T., Blümel, M., Imhoff, J. F., and Wahl, M. (2009). Specific epibacterial communities on macroalgae: phylogeny matters more than habitat. Aquatic Biology 5, 181-186. doi: 10.3354/ab00149

Lachnit, T., Meske, D., Wahl, M., Harder, T., and Schmitz, R. (2011). Epibacterial community patterns on marine macroalgae are host-specific but temporally variable. Environ. Microbiol. 13, 655-665. doi: 10.1111/j.14622920.2010.02371.x

Lage, O. (2013). Characterization of a planctomycete associated with the marine dinoflagellate Prorocentrum micans Her. Antonie Van Leeuwenhoek 104, 499-508. doi: 10.1007/s10482-013-9991-4

Lage, O., Bondoso, J., and Lobo-Da-Cunha, A. (2013). Insights into the ultrastructural morphology of novel Planctomycetes. Antonie van Leeuwenhoek, 1-10. doi: 10.1007/s10482-013-9969-2

Lage, O. M., and Bondoso, J. (2011). Planctomycetes diversity associated with macroalgae. FEMS Microbiol. Ecol. 78, 366-375. doi: 10.1111/j.15746941.2011.01168.x

Liu, M., Dong, Y., Zhao, Y., Zhang, G., Zhang, W., and Xiao, T. (2010). Structures of bacterial communities on the surface of Ulva prolifera and in seawaters in an Ulva blooming region in Jiaozhou Bay, China. World J. Microbiol. Biotechnol. 27, 1703-1712. doi: 10.1007/s11274-010-0627-9

Liu, Y., Yao, T., Jiao, N., Kang, S., Zeng, Y., and Huang, S. (2006). Microbial community structure in moraine lakes and glacial meltwaters, Mount Everest. FEMS Microbiol. Lett. 265, 98-105. doi: 10.1111/j.1574-6968.2006.00477.x

Longford, S. R., Tujula, N. A., Crocetti, G. R., Holmes, A. J., Holmström, C., Kjelleberg, S., et al. (2007). Comparisons of diversity of bacterial communities associated with three sessile marine eukaryotes. Aquat. Microb. Ecol. 48, 217-229. doi: 10.3354/ame048217

Lonhienne, T. G., Sagulenko, E., Webb, R. I., Lee, K. C., Franke, J., Devos, D. P., et al. (2010). Endocytosis-like protein uptake in the bacterium Gemmata obscuriglobus. Proc. Natl. Acad. Sci. U.S.A. 107, 12883-12888. doi: 10.1073/pnas.1001085107

Lucheta, A. R., Otero, X. L., Macías, F., and Lambais, M. R. (2013). Bacterial and archaeal communities in the acid pit lake sediments of a chalcopyrite mine. Extremophiles 17, 941-951. doi: 10.1007/s00792-013-0576-y
Matsuo, Y., Imagawa, H., Nishizawa, M., and Shizuri, Y. (2005). Isolation of an algal morphogenesis inducer from a marine bacterium. Science 307, 1598. doi: 10.1126/science.1105486

Meusnier, I., Olsen, J. L., Stam, W. T., Destombe, C., and Valero, M. (2001). Phylogenetic analyses of Caulerpa taxifolia (Chlorophyta) and of its associated bacterial microflora provide clues to the origin of the Mediterranean introduction. Mol. Ecol. 10, 931-946. doi: 10.1046/j.1365-294X.2001.01245.x

Miranda, L. N., Hutchison, K., Grossman, A. R., and Brawley, S. H. (2013). Diversity and abundance of the bacterial community of the red macroalga Porphyra umbilicalis: did bacterial farmers produce macroalgae? PLoS ONE 8:e58269. doi: 10.1371/journal.pone.0058269

Newsham, K. K., Pearce, D. A., and Bridge, P. D. (2010). Minimal influence of water and nutrient content on the bacterial community composition of a maritime Antarctic soil. Microbiol. Res. 165, 523-530. doi: 10.1016/j.micres.2009.11.005

Oliveira, F.a.S., Colares, G. B., Hissa, D. C., Angelim, A. L., Melo, V. M. M., and Lotufo, T.M.C. (2013). Microbial epibionts of the colonial ascidians Didemnum galacteum and Cystodytes sp. Symbiosis 59, 57-63. doi: 10.1007/s13199-0120210-2

Pilhofer, M., Rappl, K., Eckl, C., Bauer, A. P., Ludwig, W., Schleifer, K. H., et al. (2008). Characterization and evolution of cell division and cell wall synthesis genes in the bacterial phyla Verrucomicrobia, Lentisphaerae, Chlamydiae, and Planctomycetes and phylogenetic comparison with rRNA genes. J. Bacteriol. 190, 3192-3202. doi: 10.1128/JB.01797-07

Pimentel-Elardo, S., Wehrl, M., Friedrich, A. B., Jensen, P. R., and Hentschel, U. (2003). Isolation of planctomycetes from Aplysina sponges. Aquat. Microb. Ecol. 33, 239-245. doi: 10.3354/ame033239

Piquet, A. M. T., Bolhuis, H., Davidson, A. T., and Buma, A. G. J. (2010). Seasonal succession and UV sensitivity of marine bacterioplankton at an Antarctic coastal site. FEMS Microbiol. Ecol. 73, 68-82. doi: 10.1111/j.1574-6941.2010.00882.x

Reed, D. W., Fujita, Y., Delwiche, M. E., Blackwelder, D. B., Sheridan, P. P., Uchida, T., et al. (2002). Microbial communities from methane hydrate-bearing deep marine sediments in a forearc basin. Appl. Environ. Microbiol. 68, 3759-3770. doi: 10.1128/AEM.68.8.3759-3770.2002

Reynaud, E. G., and Devos, D. P. (2011). Transitional forms between the three domains of life and evolutionary implications. Proc. Biol. Sci. 278, 3321-3328. doi: 10.1098/rspb.2011.1581

Rusch, D. B., Halpern, A. L., Sutton, G., Heidelberg, K. B., Williamson, S., Yooseph, S., et al. (2007). The sorcerer II global ocean sampling expedition: northwest atlantic through eastern tropical pacific. PLoS Biol. 5:e77. doi: 10.1371/journal.pbio.0050077

Santarella-Mellwig, R., Franke, J., Jaedicke, A., Gorjanacz, M., Bauer, U., Budd, A., et al. (2010). The compartmentalized Bacteria of the PlanctomycetesVerrucomicrobia-Chlamydiae superphylum have membrane coat-like proteins. PLoS Biol. 8:e1000281. doi: 10.1371/journal.pbio.1000281

Santarella-Mellwig, R., Pruggnaller, S., Roos, N., Mattaj, I. W., and Devos, D. P. (2013). Three-dimensional reconstruction of bacteria with a complex endomembrane system. PLoS Biol. 11:e1001565. doi: 10.1371/journal.pbio. 1001565

Schlesner, H. (1994). The development of media suitable for the microorganisms morphologically resembling Planctomyces spp., Pirellula spp., and other Planctomycetales from various aquatic habitats using dilute media. Syst. Appl. Microbiol. 17, 135-145. doi: 10.1016/S0723-2020(11)80042-1

Schneider, D., Arp, G., Reimer, A., Reitner, J., and Daniel, R. (2013). Phylogenetic analysis of a microbialite-forming microbial mat from a hypersaline lake of the kiritimati atoll, central pacific. PLoS ONE 8:e66662. doi: 10.1371/journal.pone. 0066662

Stackebrandt, E. (2002). Report of the ad hoc committee for the re-evaluation of the species definition in bacteriology. Int. J. Syst. Evol. Microbiol. 52, 1043-1047. doi: 10.1099/ijs.0.02360-0

Tekere, M., Lötter, A., Olivier, J., Jonker, N., and Venter, S. (2011). Metagenomic analysis of bacterial diversity of siloam hot water spring, limpopo, South Africa. Afr. J. Biotechnol. 10, 18005-18012. doi: 10.5897/AJB11.899

Van Teeseling, M. C. F., Neumann, S., and Van Niftrik, L. (2013). The anammoxosome organelle is crucial for the energy metabolism of anaerobic ammonium oxidizing bacteria. J. Mol. Microbiol. Biotechnol. 23, 104-117. doi: $10.1159 / 000346547$

Wahl, M. (2008). Ecological lever and interface ecology: epibiosis modulates the interactions between host and environment. Biofouling 24, 427-438. doi: $10.1080 / 08927010802339772$ 
Ward, N., Staley, J. T., Fuerst, J. A., Giovannoni, S., Schlesner, H., and Stackebrandt, E. (2006). "The order Planctomycetales, including the genera Planctomyces, Pirellula, Gemmata and Isosphaera and the Candidatus genera Brocadia, Kuenenia and Scalindua," in The Prokaryotes: A Handbook on the Biology of Bacteria, Vol. 7, eds M. Dworkin, S. Falkow, E. Rosenberg, K. H. Schleifer, and E. Stackebrandt (New York, NY: Springer), 757-793.

Webster, N. S., and Bourne, D. (2007). Bacterial community structure associated with the Antarctic soft coral, Alcyonium antarcticum. FEMS Microbiol. Ecol. 59, 81-94. doi: 10.1111/j.1574-6941.2006.00195.x

Webster, N. S., Wilson, K. J., Blackall, L. L., and Hill, R. T. (2001). Phylogenetic diversity of bacteria associated with the marine sponge Rhopaloeides odorabile. Appl. Environ. Microbiol. 67, 434-444. doi: 10.1128/AEM.67.1.434-44 4.2001

Wecker, P., Klockow, C., Ellrott, A., Quast, C., Langhammer, P., Harder, J., et al. (2009). Transcriptional response of the model Planctomycete Rhodopirellula baltica $\mathrm{SH}^{(T)}$ to changing environmental conditions. BMC Genomics 10:410. doi: 10.1186/1471-2164-10-410

Wegner, C. E., Richter-Heitmann, T., Klindworth, A., Klockow, C., Richter, M., Achstetter, T., et al. (2013). Expression of sulfatases in Rhodopirellula baltica and the diversity of sulfatases in the genus Rhodopirellula. Mar. Genomics 9, 51-61. doi: 10.1016/j.margen.2012.12.001

Winkelmann, N., and Harder, J. (2009). An improved isolation method for attached-living Planctomycetes of the genus Rhodopirellula. J. Microbiol. Methods 77, 276-284. doi: 10.1016/j.mimet.2009.03.002

Yakimov, M. M., Cappello, S., Crisafi, E., Tursi, A., Savini, A., Corselli, C., et al. (2006). Phylogenetic survey of metabolically active microbial communities associated with the deep-sea coral Lophelia pertusa from the Apulian plateau, Central Mediterranean Sea. Deep-Sea Res. I 53, 62-75. doi: 10.1016/j.dsr.2005.07.005

Yoon, J., Jang, J. H., and Kasai, H. (2014). Algisphaera agarilytica gen. nov., sp. nov., a novel representative of the class Phycisphaerae within the phylum
Planctomycetes isolated from a marine alga. Antonie Van Leeuwenhoek 105, 317-324. doi: 10.1007/s10482-013-0076-1

Zeng, Y. X., Yan, M., Yu, Y., Li, H. R., He, J. F., Sun, K., et al. (2013). Diversity of bacteria in surface ice of Austre Lovénbreen glacier, Svalbard. Arch. Microbiol. 195, 313-322. doi: 10.1007/s00203-013-0880-Z

Zhang, W., Wu, X., Liu, G., Chen, T., Zhang, G., Dong, Z., et al. (2013). Pyrosequencing reveals bacterial diversity in the rhizosphere of three phragmites australis ecotypes. Geomicrobiol. J. 30, 593-599. doi: 10.1080/01490451.2012.740145

Zhao, Z., Luo, K., Chen, G., Yang, Y., Mao, Z., Liu, E., et al. (2010). Analysis of bacterial diversity in rhizosphere of cucumber in greenhouse by the methods of metagenomic end-random sequencing and 16S rDNA technology. Shengtai Xuebao/ Acta Ecologica Sinica 30, 3849-3857.

Zhu, P., Li, Q., and Wang, G. (2008). Unique microbial signatures of the alien hawaiian marine sponge Suberites zeteki. Microb. Ecol. 55, 406-414. doi: $10.1007 /$ s00248-007-9285-3

Conflict of Interest Statement: The authors declare that the research was conducted in the absence of any commercial or financial relationships that could be construed as a potential conflict of interest.

Received: 28 March 2014; accepted: 15 May 2014; published online: 03 June 2014. Citation: Lage OM and Bondoso J (2014) Planctomycetes and macroalgae, a striking association. Front. Microbiol. 5:267. doi: 10.3389/fmicb.2014.00267

This article was submitted to Terrestrial Microbiology, a section of the journal Frontiers in Microbiology.

Copyright (c) 2014 Lage and Bondoso. This is an open-access article distributed under the terms of the Creative Commons Attribution License (CC BY). The use, distribution or reproduction in other forums is permitted, provided the original author(s) or licensor are credited and that the original publication in this journal is cited, in accordance with accepted academic practice. No use, distribution or reproduction is permitted which does not comply with these terms. 